\title{
Trust in the Russian economy and business environment
}

\author{
Viktor Barkhatov ${ }^{1}$, Daria Benz ${ }^{1}$, and Dmitri Pletnev1, \\ ${ }^{1}$ Chelyabinsk State University, Chelyabinsk, Russia
}

\begin{abstract}
Institutional aspects of business become more and more pertinent. Russian enterprises acts in the environment that is currently imperfect and does not provide comfortable conditions for the growth of small and medium enterprises. Trust is the foundation for construction of a friendly institutional environment, a basic institution required for cooperation between any kinds of subjects. Large enterprises are the core of the Russian economy, they are a stable source of financing the federal budget. Small and medium-sized businesses face two complexities: weak government support and in a business environment characterized by a low level of trust. The purpose of the article is to assess the interrelation of trust indicators in the Russian economy with the main economic indicators using methods of correlation and regression analysis. The parameters of the models are evaluated on the basis of the data of VCIOM (The Russian Public Opinion Research Center) and Rosstat (Russian State Statistics Agency). The main conclusion of the study is the most significant impact on the economy of such a trust indicator as the index of favorable conditions for making large purchases. This indicator can be used for modeling and managing the economic growth in the modern Russian economy.
\end{abstract}

\section{Introduction}

The Russian economy is developing as an important part of the Eurasian economic space, as a key member of BRICS and SCO. Integration of economies, building economic ties requires a healthy and sustainable business environment that is friendly to the many parties involved in its work. A friendly environment is the term that is gaining popularity in business circles. Institutional environment is formed, as a rule, spontaneously, and it is extremely difficult to control the process of creating a friendly institutional environment from above. It is almost impossible. Trust is the foundation for creating a friendly institutional environment, the basic institution, which in principle is necessary for interaction between any subjects. Trust became the theme of the St. Petersburg International Economic Forum in 2018. The reason for this is that for the Russian economy the problem of trust is one of the most important. The revolutionary economic changes that took place in the 1990s completely violated existing economic ties, changed the personal composition of the subjects and permissible forms of interaction. Over the years since then,

\footnotetext{
*Corresponding author: pletnev@csu.ru
} 
sprouts of trust have appeared, but they are not the basis for building long-term partnerships so far. The purpose of the article is to assess the interrelation of trust indicators in the Russian economy with the main economic indicators.

\section{Literature Review}

The concept of trust has several different interpretations in economic research. Lane (2000) defines trust as the belief or expectation that potential loss, which can occur due to the cooperation risk, will not become a benefit for another organization. In other words, trust in the Economics is the expectation of honesty in the distribution of potential losses between counterparties. This is a rather narrow definition, and applies primarily to the conditions of transactions of a market type. A wider understanding of trust can be found in Giddens (1990): confidence in the reliability of a person or system in relation to a certain series of events or phenomena. This approach can be used as a starting point, but not as a concrete way of studying the phenomenon of trust in detail, for this it is too general. An important aspect of understanding trust is its reciprocal character Coleman (1990). However, a situation is possible when this reciprocity is not realized for example, we trust the deputy or the mayor whom we choose, but he does not necessarily trust us. In this case, the reciprocity is reduced to the expectation that the person who is trusted (trustee) will behave decently towards the trustors.

Researchers of trust in the economy talk about two established scientific traditions: institutional and sociological. Representatives of the first (including Williamson (1993)) link the notion of trust with the established system of institutions. They point to the difference in levels of trust in different countries due to different "cultural codes", which are described by a set of formal and informal institutions. Neoinstitutionalists add to this approach the concept of rational choice: trust is possible when the benefits of trust outweigh the possible losses in updating risks. This approach is described in Furlong (1996), Humphrey, Schmitz (1996). It can be used only to describe collective processes, when individual choices are aggregated and averaged: when risks increase, public trust becomes less, and vice versa. When analyzing specific behavioral patterns, this approach unduly formalizes the situation. Alternative, sociological approach Grannovetter (1985), Radaev (2012); Veselov, Sinyutin, Kapustkina, (2016) points to the importance of repetitive interactions and embedded connections of actors to build trust, while trust from the interpersonal phenomenon becomes a social one.

Henry and Dietz (2011) relating to the study of the problem of public resources, investigated trust as a complex social phenomenon manifested in conscious behavior, in which the results of some people depend on the actions and results of others. As the authors note, the trust defined in this way has two limitations. The first concerns the fact that it ignores quite a wide range of phenomena described by the same word "trust" - it is about trust in the exchange of information. In contrast to the "dynamic" trust "in action", trust in information is a static phenomenon, and it exists regardless of the specific actions of the actor. For example, a person may or may not trust advertising, or not trust the results of a scientific study of a new drug. However, this restriction can be removed when considering advertisement or scientific research as a "past" action of those who created them, and trust in relation to a possible future action of the actor.

The second limitation concerns the direct nature of trust, which is usually considered. It's about inter-subject interaction: interaction of person to person is usually described, although in real social systems, trust most often arises in a network way: A trusts $\mathrm{B}, \mathrm{B}$ trusts $\mathrm{C}, \mathrm{C}$ trusts $\mathrm{D}$, etc. As a result, A indirectly trusts D. A circle (star, triangle) of trust is formed. These kinds of relations occupy an intermediate position between personal trust and generalized trust, inherent in the whole society. However, they are rarely considered as 
the object of study. The exception is the classic work by Grannovetter (1985), as well as the works by Bodin and Crona (2009) and Sandström and Rova (2010), devoted to building trust in networking.

A detailed analysis of the forms of trust in the economy is given in the work by Hakanen et al. (2016). He identifies four levels of trust: individual, network, organizational, and public trust. He especially pays attention to individual trust, highlighting at this level initial, on-going, calculus-based, generalized, fragile and resilient trust. Tejpal, Garg and Sachdeva (2013) offer an alternative classification of trust forms: Characteristic, Rational, Institutional, Anticipatory, Responsive, Calculus-based trust and identification-based trust. Earlier work by Zucker (1986) described three alternative forms of organizational trust: process-based, characteristic-based, Institutional-based. Sako (1992) described three other forms of trust: contractual, competence and voluntary trust. There is a slightly strange definition of each of these forms: contractual - is a commitment to honesty and fulfillment of promises, competence - based - is an expectation of honesty in transactions, and voluntary trust - is a willingness to share unexpectedly large result of common activity with a partner.

Fehr (2009) conducted an interesting study of factors influencing trust. He identified four common factors of trust: first, subject's propensity for risk, second, the inertia in perception of the past experience - once deceived, one person will always be on guard, and the other will remain optimistic and a priori trust in people. The third factor is the degree of altruism, the readiness to abandon selfishness in favor of following the common interests. The fourth factor is the nature of people's perception of others: how high is the probability that they (others) will also show trust in return. The first three of these factors are rather constant and have a stable level within a single society. The fourth factor can change relatively quickly.

The phenomenon of trust is often the subject of interesting applied research. Edelman Trust Barometer (Edelman (2018)) is widely known. Krot, Lewicka (2012) determined the dependence of the dimensions of trust (three dimensions of trust (competence, benevolence and integrity)) and various types of intra-firm relations on the example of the Polish company. Different perceptions of trust were established in horizontal relationships (manager-manager or employee-employee) and vertical relationships (manager-employee). It was stated that trust in organizations has a complex structure, and does not act as an integral phenomenon. Skinner, Spira (2003) examined trust in the business environment as a factor complementing the control and allowing to increase the effectiveness of the entire management system. Batt (2003) explore trust relationship between Growers and Market Agents in agricultural sector. Consumer trust as important part of marketing competences of firms and its success factor studied in Sirdeshmukh, Singh, and Sabol (2002) and Young and Albaum (2003). Trust as a factor for development of shadow economy and building informal networks considered in D'Hernoncourt and Meon (2012) and Elgin and Erturk (2018). Kazlauskienè and Bartuševičienè (2013) conducted a study of the importance of behavior criteria in the assessment of trust in inter-firm relations through a survey of University graduates in Lithuania. It was established that trust is most strongly associated with honesty/promise keeping, goodwill/altruism, tolerance, respect, tactfulness. The connection of trust with such characteristics of human interaction as foresight/perceptiveness, competition/ability, reputation/image is weaker. The majority of studies are characterized by the difficulty associated with the complexity of trust and economic assessments and their "integration" into the system of standard economic indicators. There are also no estimates and models of trust in the Russian economy in the literature. 


\section{Methodology and Data}

Trust is considered as a condition for the development of entrepreneurial activity. Entrepreneurial activity is one of the engines of economic growth. In turn, entrepreneurial (investment) activity becomes possible in conditions of favorable consumer expectations. Therefore, in this study, as indexes of trust, there will be used not only indexes reflecting the expectations of entrepreneurs, but also indexes of consumer expectations. Confidence indexes are proposed to be investigated along with trust indexes. The object of the study is the Russian economy. The sample includes time series of the maximum possible duration. The indexes of consumer trust and credit trust are available for the period 2008 (2009) 2018. The index of entrepreneurial confidence is available for the period $2005-2017$. The values of all other indexes are for the period 1999 - 2018. Most of them are available not only averaged over the year, but quarterly.

As indicators of trust, there will be used five indexes: consumer trust, credit trust, consumer confidence, current personal financial situation, changes in personal financial situation for the year, the expected changes in personal financial situation in a year, favorable conditions for large purchases, favorable conditions for savings, entrepreneurial confidence. The first two indexes were calculated by VCIOM - The Russian Public Opinion Research Center. Other indexes were calculated by Rosstat (Russian State Statistics Agency). Figure 1 shows the dynamics of consumer trust and credit trust indexes.

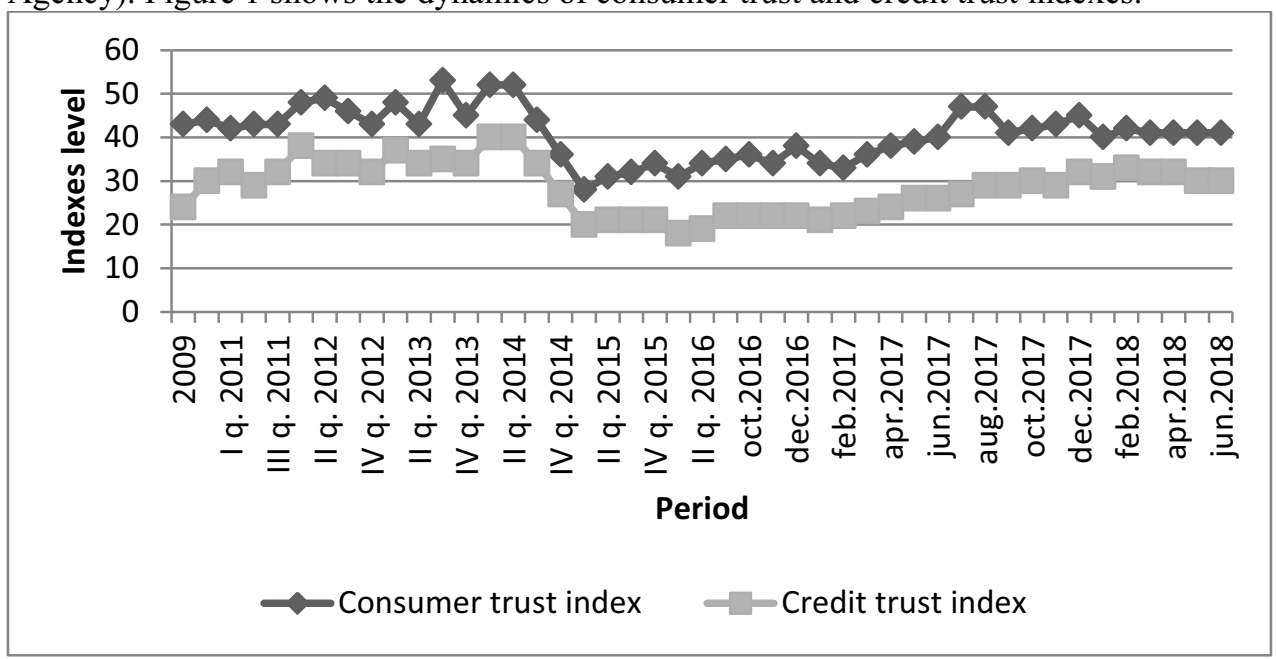

Source: Data provided by the Russian Public Opinion Research Center VCIOM (2018a, 2018b).

Fig. 1. Dynamics of Consumer Trust and Credit Trust Indexes.

The consumer trust index shows how favorable the Russians consider the current time for making large purchases. The index is computed on the basis of the question: "Is it a good time now to make large purchases or not?" The answer "Rather good" is assigned a coefficient of 0.9 , the answer "Rather bad" - 0.1, "I am at a loss to answer" - 0.5. The index is measured in points and can range from 10 to 90 . The higher the index value, the more favorable the Russians consider the current moment for large acquisitions. The credit trust index shows how favorable the Russians consider the current time for lending. The index is computed on the basis of the question: "Is it a good time now to take out loans or not?". The answer "Rather good" is assigned a coefficient of 0.9 , the answer "Rather bad" - 0.1, "I am at a loss to answer" - 0.5. The index is measured in points and can range from 10 to 90 . The higher the index value, the more favorable the Russians consider the current moment for taking a loan. Other indexes of trust are evaluated in the same way. 
To build the model, the following methodology is used: the coefficients of pair correlation between the indicated trust indexes and the main economic indicators are calculated. The following indicators are used as economic ones: GDP in current prices, GDP in fixed prices, the share of innovative enterprises, investment in fixed-capital assets, the unemployment rate, the number of people with incomes below the subsistence minimum, the number of registered crimes. All indicators are available on the Rosstat website. Calculations will also include time-lagged correlations.

Next step of the study is to construct a linear multiple regression model of the form:

$$
\mathrm{Y}=\mathrm{k}_{1} \mathrm{X}_{1}+\mathrm{k}_{2} \mathrm{X}_{2}+\ldots+\mathrm{k}_{\mathrm{n}} \mathrm{X}_{\mathrm{n}}+\mathrm{b}
$$

Where:

$\mathrm{Y}-\mathrm{GDP}$ in fixed prices,

$\mathrm{Xi}$ - independent variables,

$\mathrm{ki}$ - parameters,

b - Y-intercept.

The indexes and economic indicators which at the stage of correlation calculation showed a relatively close interrelation with real GDP (correlation coefficient above 0.6) will be included in the model as independent variables. Further, the model will be tested (including autocorrelation test).

\section{Results}

The averaged values of trust indexes are calculated by the years based on quarterly data (Fig. 2 and 3). There is some commonality between all indexes at the moment: trust and confidence have similar dynamics, with two local minimum (in 2009 and in 2015). For a number of indexes, the pre-crisis 2008 level has not been reached yet. Figure 3 shows the dynamics of the index of entrepreneurial confidence in manufacturing enterprises, also calculated on Rosstat data. 


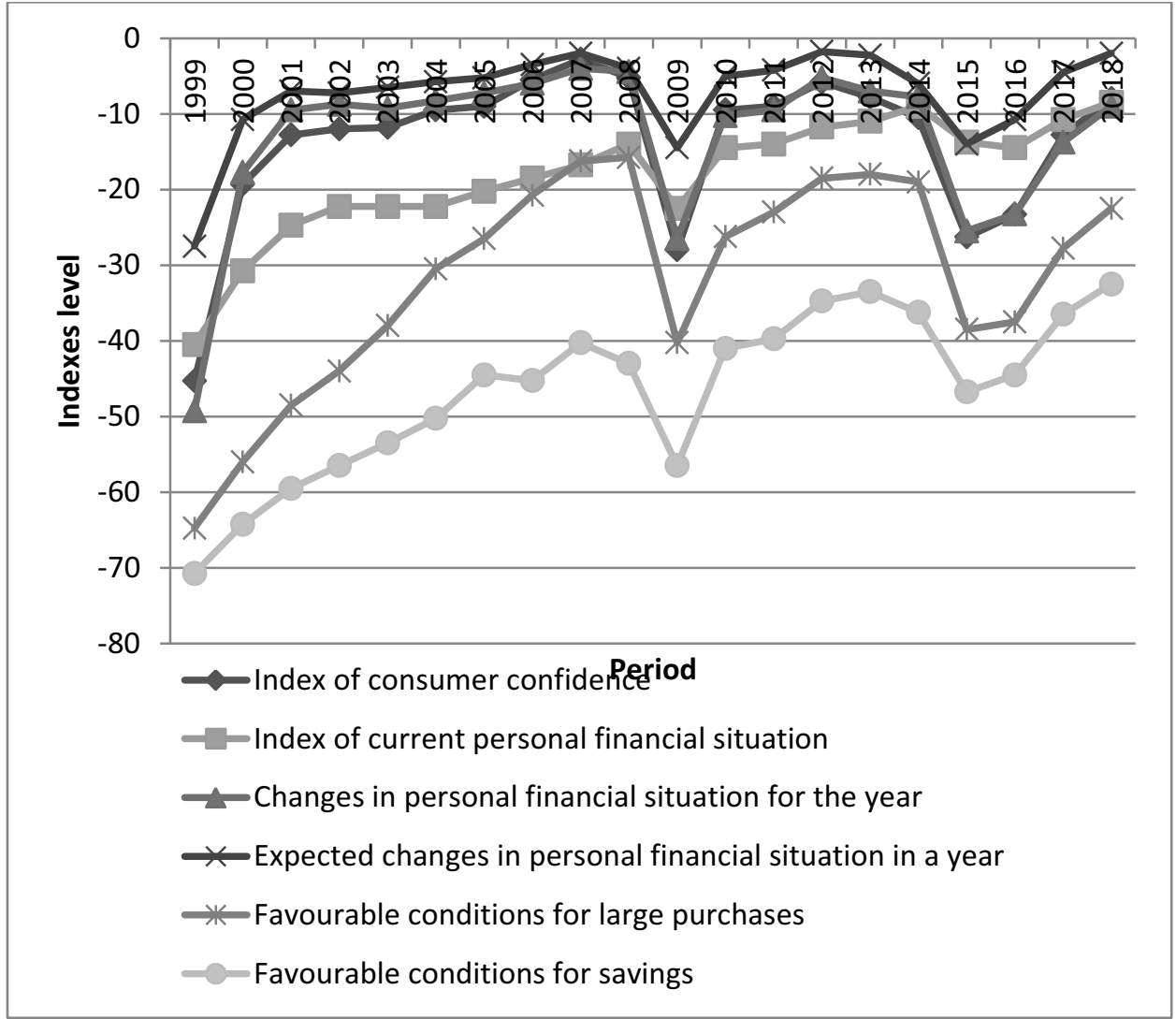

Source: calculated by authors according to the Rosstat (2018a).

Figure 2. Dynamics of Indexes Characterizing Consumer Confidence.

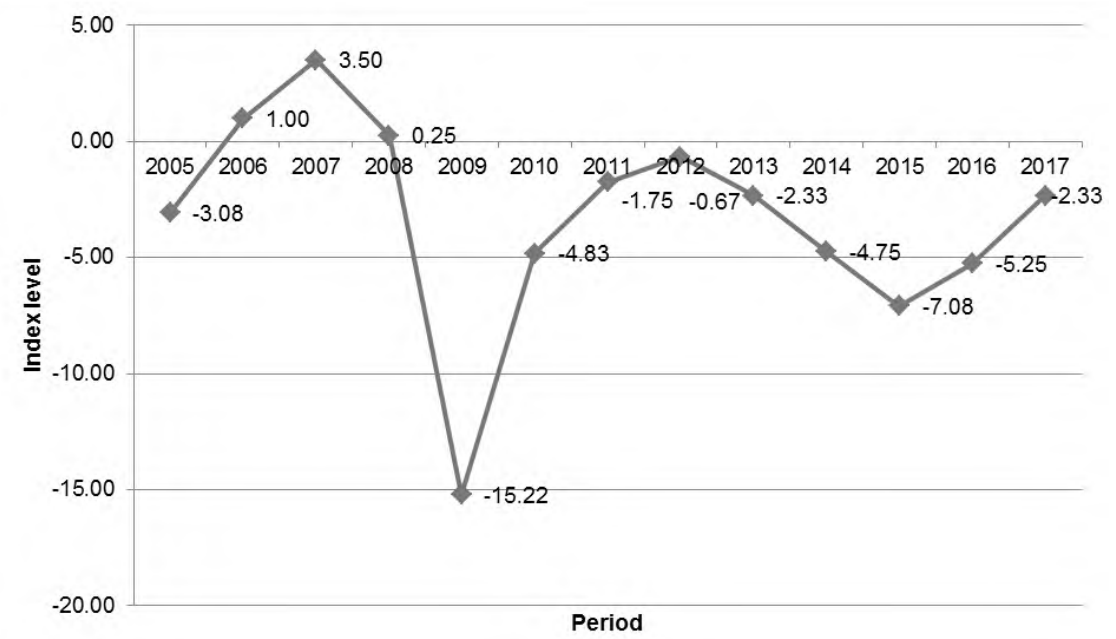

Source: calculated by authors according to the Rosstat (2018b).

Figure 3. Dynamics of the Index of Entrepreneurial Confidence in Manufacturing Enterprises. 
The correlation analysis was conducted without taking into account the time lag and taking into account the time lag of one year. Indexes reflecting the mood of the population (consumers and entrepreneurs) may be a consequence of changes in the economic situation of the country. Consequently, the reaction of the population may be somewhat delayed. A sample for calculating the correlation between trust / confidence indexes and GDP in current prices were quarterly values for the period from 1 quarter of 1999 to 1 quarter of 2018. Here the time lag is one quarter. This decision was made to increase the sample. In all other cases, annual data for the same period serve as a sample, due to the absence of quarterly statistics on economic indicators. In these cases, the time lag is one year. The results of the correlation analysis are presented in Table 1. The values of correlation coefficients taking into account the time lag are given in brackets.

Table 1. Results of the Correlation Analysis.

\begin{tabular}{|c|c|c|c|c|c|c|c|}
\hline Indexes & $\begin{array}{l}\text { GDP in } \\
\text { current } \\
\text { prices }\end{array}$ & $\begin{array}{l}\text { GDP iin } \\
\text { fixed } \\
\text { prices }\end{array}$ & $\begin{array}{c}\text { Share of } \\
\text { innovative } \\
\text { enterprises }\end{array}$ & $\begin{array}{l}\text { Investments } \\
\text { in fixed- } \\
\text { capital } \\
\text { assets }\end{array}$ & $\begin{array}{l}\text { Number of } \\
\text { people } \\
\text { with } \\
\text { incomes } \\
\text { below the } \\
\text { subsistence } \\
\text { minimum }\end{array}$ & $\begin{array}{l}\text { Unemploy- } \\
\text { ment rate }\end{array}$ & $\begin{array}{l}\text { Number } \\
\text { of } \\
\text { crimes }\end{array}$ \\
\hline Consumer confidence & $\begin{array}{c}0.11 \\
(0.12)^{*}\end{array}$ & $\begin{array}{c}0.31 \\
(0.33)\end{array}$ & $\frac{\mathbf{0 . 6 8}}{(0.53)}$ & $\begin{array}{c}0.14 \\
(0.16)\end{array}$ & $\begin{array}{l}-0.15 \\
(-0.18)\end{array}$ & $\frac{\mathbf{- 0 . 6 2}}{(-0.56)}$ & $\begin{array}{c}0.34 \\
(0.42)\end{array}$ \\
\hline $\begin{array}{l}\text { Current personal } \\
\text { financial situation }\end{array}$ & $\underline{\underline{0.80}}$ & $\underline{\underline{0.91}}$ & $\begin{array}{c}0.24 \\
(-0.06)\end{array}$ & $\underline{\underline{0.83}}$ & $\frac{-0.87}{(-0.85)}$ & $\frac{-0.98}{(-0.89)}$ & $\frac{-0.75}{(-0.63)}$ \\
\hline $\begin{array}{l}\text { Changes in personal } \\
\text { financial situation for } \\
\text { the year }\end{array}$ & $\begin{array}{c}0.09 \\
(0.08)\end{array}$ & $\begin{array}{c}0.27 \\
(0.26)\end{array}$ & $\frac{\mathbf{0 . 6 9}}{(0.50)}$ & $\begin{array}{c}0.11 \\
(0.12)\end{array}$ & $\begin{array}{c}-0.03 \\
(-.0 .08)\end{array}$ & $\frac{\mathbf{- 0 . 6 1}}{(-0.54)}$ & $\begin{array}{c}0.34 \\
(0.43)\end{array}$ \\
\hline $\begin{array}{l}\text { Expected changes in } \\
\text { personal financial } \\
\text { situation in a year }\end{array}$ & $\begin{array}{c}0.23 \\
(0.24)\end{array}$ & $\begin{array}{c}0.43 \\
(0.43)\end{array}$ & $\underline{\underline{0.70}} \underline{(0.60)}$ & $\begin{array}{c}0.28 \\
(0.30)\end{array}$ & $\begin{array}{c}-0.27 \\
(-0.29)\end{array}$ & $\frac{-0.70}{(-0.64)}$ & $\begin{array}{c}0.17 \\
(0.29)\end{array}$ \\
\hline $\begin{array}{l}\text { Favorable conditions } \\
\text { for large purchases }\end{array}$ & $\begin{array}{c}0.51 \\
(0.51)\end{array}$ & $\underline{\underline{0.73}}$ & $\frac{\mathbf{0 . 7 0}}{(0.36)}$ & $\begin{array}{c}0.56 \\
(0.59)\end{array}$ & $\frac{-0.80}{(-0.80)}$ & $\frac{-0.84}{(-0.77)}$ & $\begin{array}{c}0.23 \\
(0.28)\end{array}$ \\
\hline $\begin{array}{l}\text { Favorable conditions } \\
\text { for savings }\end{array}$ & $\underline{0.73}$ & $\underline{0.88}$ & $\begin{array}{c}0.57 \\
(0.32)\end{array}$ & $\underline{0.78}$ & $\frac{-0.86}{(-0.84)}$ & $\frac{-0.92}{(-0.88)}$ & $\begin{array}{l}-0.45 \\
(-0.27)\end{array}$ \\
\hline Credit trust & $\begin{array}{c}-0.47 \\
(-0.48)\end{array}$ & $\begin{array}{c}0.14 \\
(0.06)\end{array}$ & $\frac{\mathbf{0 . 8 0}}{(0.54)}$ & $\begin{array}{l}-0.15 \\
(-0.23)\end{array}$ & $\frac{\mathbf{- 0 . 7 5}}{(-0.48)}$ & $\begin{array}{l}-0.24 \\
(-0.14)\end{array}$ & $\begin{array}{l}-0.03 \\
(0.03)\end{array}$ \\
\hline Consumer trust & $\begin{array}{c}-0.38 \\
(-0.34)\end{array}$ & $\begin{array}{l}-0.12 \\
(-0.04)\end{array}$ & $\underline{0.73}$ & $\begin{array}{l}-0.35 \\
(-0.45)\end{array}$ & $\frac{\mathbf{- 0 . 7 7}}{(-0.58)}$ & $\begin{array}{c}0.12 \\
(0.004)\end{array}$ & $\begin{array}{c}0.07 \\
(0.22)\end{array}$ \\
\hline $\begin{array}{l}\text { Entrepreneurial } \\
\text { confidence }\end{array}$ & $\begin{array}{l}-0.16 \\
(-0.10)\end{array}$ & $\begin{array}{l}-0.02 \\
(-0.07)\end{array}$ & $\begin{array}{c}0.47 \\
(0.24)\end{array}$ & $\begin{array}{l}-0.26 \\
(-0.18)\end{array}$ & $\begin{array}{c}0.05 \\
(-0.001)\end{array}$ & $\begin{array}{l}-0.40 \\
(-0.12)\end{array}$ & $\begin{array}{c}0.32 \\
(0.33)\end{array}$ \\
\hline
\end{tabular}

Source: Calculated by authors

* - values for lagged correlation

The time lag in most cases does not matter. The values of the correlation coefficients do not differ significantly. Table 1 allows to conclude that the closest interrelation of real GDP is observed with three indexes - the index of current financial situation, the index of favorable conditions for large purchases, the index of favorable conditions for savings. To construct a regression model GDP in fixed prices (Y) is taken as a dependent variable. Independent variables are the following six indicators: investment in fixed-capital assets (X1), unemployment rate (X2), the population with incomes below the subsistence minimum (X3), the index of the current financial situation (X4), the index of favorable conditions for large purchases (X5) and the index of favorable conditions for savings (X6). 
The growth rates of the corresponding indicators rather than the quantities themselves are used to exclude the influence of the autocorrelation on the model. In this case, a regression of the form is obtained (formula 2):

$$
\begin{gathered}
\mathrm{Y}=0.174 \mathrm{X}_{1}-0.046 \mathrm{X}_{2}+0.027 \mathrm{X}_{3}+0.073 \mathrm{X}_{4}-0.082 \mathrm{X}_{5}+0.04 \mathrm{X}_{6}+0.83 \\
\left(\begin{array}{lllllll}
0.074) & (0.115) & (0.097) & (0.071) & (0.049) & (0.111) & (0.173)
\end{array}\right.
\end{gathered}
$$

The obtained model is characterized by the following properties: the adjusted R-squared is 0.73 ; the regression is statistically significant at $5 \%$ level; however, of all the coefficients, only three are significant - the free term, the parameters $\mathrm{k} 1$ and $\mathrm{k} 5$. Thus, of all the studied indexes of trust and confidence only the index of favorable conditions for large purchases influences the real economic growth.

\section{Conclusion}

Trust can be viewed as the result of economic changes in the country. On the other hand, trust can be a condition for changes. The conducted correlation analysis (in particular, the idea of a time lag) was based on the premise that trust is the result of the occurred changes. The regression model was built based on the second idea. The study showed a close correlation between some trust and confidence indexes and economic indicators characterizing the state of the national economy. In particular, the population feels more confident in the current financial situation as both nominal and real GDP grows. Moreover, the unemployment rate is reversed and closely related to such confidence. Moreover, the higher the crime rate, the lower the population's confidence in the financial situation. The indexes of favorable conditions for large purchases and for savings in general repeat the dynamics of the index of the current personal financial situation.

Consumer and credit trust indexes are less explained by the dynamics of the economic indicators. There is no connection with the dynamics of GDP, with the dynamics of investment in fixed-capital assets and even with the level of unemployment and crime. This leads to a bold conclusion: trust and confidence are completely different categories. Meanwhile, there is a link between trust and poverty - the higher the population size with incomes below the subsistence minimum, the lower consumer and credit trust. An interesting result is the link between trust and the share of innovative enterprises in the country. The regression model showed that, among all confidence indexes, only the index of favorable conditions for large purchases predetermines the economic growth to some extent. On the other hand, the reverse influence cannot be denied: the population of the country only feels the possibility of large acquisitions when its economic well-being grows. And this growth is due to the growth of real GDP. Trust in Russia has not yet become a condition for economic growth. Trust is a consequence rather than a condition of economic growth. In addition, the study showed that there is no significant link between business confidence and economic indicators. Consequently, the question of development of investment expectations alongside with the entrepreneurial confidence remains open.

The research was carried out with the financial support of the Institute of Economics of Industry, Business and Administration at Chelyabinsk State University.

\section{References}

1. Batt, P. J., 2003 Building Trust between Growers and Market Agents. Supply Chain Management: An International Journal. Vol. 1(8), pp. 65-78 
2. Bodin, Ö. and Crona, B. I., 2009. The Role of Social Networks in Natural Resource Governance: What Relational Patterns Make a Difference? Global Environmental Change vol. 19(3), pp.366-374.

3. Coleman J. 1990. Foundations of Social Theory. The Belknap Press of Harvard University Press: Cambridge, MA; London, England.

4. D'Hernoncourt, J., \& Meon, P. G., 2012. The not so dark side of trust: Does trust increase the size of the shadow economy? Journal of Economic Behavior and Organization, 81(1), 97-121.

5. Edelman, 2018. Edelman Trust Barometer [online] <https://www.edelman.com/trustbarometer, accessed 18.07.2018>, Accessed 05.08.2018

6. Elgin, C. \& Erturk, F., 2018. Informal economies around the world: measures, determinants and consequences. Eurasian Economic Review (in press) pp. 1-17.

7. Fehr, E., 2009. On the Economics and Biology of Trust. Journal of the European Economic Association vol. 7(2-3), pp.235-266.

8. Furlong D., 1996. The Conceptualization of "Trust" In Economic Thought. University of Sussex. Institute of Development Studies: Brighton, England.

9. Giddens A. 1990. The Consequences of Modernity. Polity Press: Cambridge

10. Granovetter M., 1985. Economic action and social structure: The problem of embeddedness. American Journal of Sociology, vol. 91(3), pp. 481-510

11. Hakanen et al., 2016. Building Interpersonal Trust in Business Networks: Enablers and Roadblocks, Journal of Business Models, vol. 4, no. 1, pp. 45-62

12. Henry, A.D. and Dietz, Th., 2011. Information, networks, and the complexity of trust in commons governance. International Journal of the Commons. Vol. 5, no 2, pp. 188212

13. Humphrey J., Schmitz H. 1996. Trust and Economic Development. Mimeo, Institute of Development Studies, University of Sussex

14. Kazlauskienè, E., and Bartuševičienè, I., 2013. Trust Dimensions in the Business Relationship. Intellectual Economics, Vol. 7, No. 4(18), pp. 497-509

15. Krot K., and Lewicka, D., 2012. The Importance of Trust in Manager-Employee Relationships International Journal of Electronic Business Management, Vol. 10, No. 3, pp. 224-233

16. Lane, J. E., 2000. New Public Management, London: Routledge.

17. Radaev V., 2012. On Class and Personal Trust. Harvard Business Review, Russia vol. 10. https://hbr-russia.ru/biznes-i-obshchestvo/ekonomika/a11427 (accessed: 18.07.2018)

18. Rosstat, 2018a. Potrebitel'skiye ozhidaniya v Rossii [Consumer expectations in Russia] [online] <http://www.gks.ru/bgd/free/b04_03/IssWWW.exe/Stg/d03/65.htm> Accessed 05.08.2018

19. Rosstat, 2018b. Indeks predprinimatel'skoy uverennosti obrabatyvayushchikh proizvodstv [Index of entrepreneurial confidence in manufacturing industries] [online] $<$ http://www.gks.ru/free_doc/new_site/business/prom/uver-op.xls> Accessed 05.08.2018

20. Sako, M., 1992. Price, Quality, And Trust: Inter-Firm Relations in Britain and Japan, Cambridge University Press: Cambridge 
21. Sandström, A. and Rova, C., 2010. The Network Structure of Adaptive Governance: A Single Case Study of a Fish Management Area. International Journal of the Commons vol. 4(1), pp. 528-551.

22. Sirdeshmukh, D., Singh, J., and Sabol, B., 2002. Consumer Trust, Value, and Loyalty in Relational Exchanges. The Journal of Marketing, vol. 66, 15-37.

23. Skinner, D.; Spira, L. F. 2003. Trust and Control - A Symbiotic Relationship? Corporate Governance: The international journal of business in society, vol. 4(3), pp. 28-35.

24. Tejpal, G., Garg, R.K., and Sachdeva, A. 2013. Trust among Supply Chain Partners: A Review. Journal Measuring Business Excellence. Vol. 1(17), pp. 51-71.

25. Tejpal, G.; Garg, R.K.; Sachdeva, A. 2013. Trust among Supply Chain Partners: A Review. Journal Measuring Business Excellence. vol. 1(17), pp. 51-71.

26. VCIOM, 2018a. Indeks potrebitelskogo doveriya [Consumer confidence index] [online] $<$ https://wciom.ru/news/ratings/indeks_potrebitelskogo_doveriya/>, Accessed 05.08.2018

27. VCIOM, 2018b. Indeks kreditnogo optimizma (doveriya) [Credit optimism (confidence) index], [online] $<$ http://wciom.ru/news/ratings/indeks_kreditnogo_doveriya/>, Accessed 05.08.2018

28. Veselov Yu., Sinyutin M., Kapustkina E., 2016. Trust, Morality, and Markets: Rethinking Economy and Society via the Russian Case. Peter Lang: Frankfurt am Main.

29. Williamson, O. E. 1993. Calculativeness, trust, and economic organization. The Journal of Law and Economics, vol. 36, pp. 453-486

30. Young, L., and Albaum, G., 2003. Measurement of trust in salesperson-customer relationships in direct selling. Journal of Personal Selling \& Sales Management, vol. 23(3), pp.253-269.

31. Zucker, L.G., 1986. The Production of Trust: Institutional Sources of Economic Structure, 1840-1920. Research in Organizational Behavior, vol. 8, pp. 53-111. 